\title{
Article \\ From Ephemeral Planning to Permanent Urbanism: An Urban Planning Theory of Mega-Events
}

\author{
Eva Kassens-Noor
}

School of Planning, Design and Construction \& Global Urban Studies, Michigan State University, 48824 East Lansing, USA; E-Mail: ekn@msu.edu

Submitted: 15 December 2015 | Accepted: 1 March 2016 | Published: 10 March 2016

\begin{abstract}
Mega-events like the Olympic Games are powerful forces that shape cities. In the wake of mega-events, a variety of positive and negative legacies have remained in host cities. In order to bring some theoretical clarity to debates about legacy creation, I introduce the concepts of the mega-event utopia, dystopia and heterotopia. A mega-event utopia is ideal and imaginary urbanism embracing abstract concepts about economies, socio-political systems, spaces, and societies in the host during events. The mega-event utopia (in contrast to other utopian visions other stakeholders may hold) is dictated by the desires of the mega-event owners irrespective of the realities in the event host. In short, a megaevent utopia is the perfect event host from the owner's perspective. Mega-event utopias are suggested as a theoretical model for the systematic transformation of their host cities. As large-scale events progress as ever more powerful transformers into this century, mega-event dystopias have emerged as negatives of these idealistic utopias. As hybrid post-event landscapes, mega-event heterotopias manifest the temporary mega-event utopia as legacy imprints into the long-term realities in hosting cities. Using the Olympic utopia as an example of a mega-event utopia, I theorize utopian visions around four urban traits: economy, image, infrastructure and society. Through the concept of the mega-event legacy utopia, I also provide some insight toward the operationalization of the four urban traits for a city's economic development, local place marketing, urban development, and public participation.
\end{abstract}

\section{Keywords}

heterotopia; legacy; mega-event; Olympic; place; planning theory; society; transformation; urban theory; utopia

\section{Issue}

This article is part of the issue "Urban Forms and Future Cities", edited by Luca D'Acci (Erasmus University Rotterdam, The Netherlands), Tigran Haas (KTH Royal Institute of Technology, Sweden) and Ronita Bardhan (Indian Institute of Technology Bombay, India).

(C) 2016 by the author; licensee Cogitatio (Lisbon, Portugal). This article is licensed under a Creative Commons Attribution 4.0 International License (CC BY).

\section{Introduction}

Large-scale events such as the Olympic Games are temporary celebrations of creativity, athleticism, and excellence. They attract millions of people and have international media coverage. Mega-events permanently transform their hosts in the processes of bidding, planning, and staging (Essex \& Chalkley, 1998; Grix \& Carmichael, 2011; Hiller, 2000; Horne, 2007; Müller, 2015c). A critical comparison of the many recent publications on urban transformations through mega-events indicates a series of tensions and discrepancies in planning for mega-events and their impacts (also called legacies) for host nations: mega-events can accelerate existing urban plans (Essex \& Chalkley, 1998) or create new ones (Kassens-Noor, 2012); revitalize urban areas (Cashman, 2011; Smith, 2012) or create structures burdening hosts (Gaffney, 2010); are able to produce temporary legacies (Gratton \& Preuss, 2008) or leverage legacies long-term (Grix, 2014; Smith, 2014). Amidst this uncertainty about legacies, I attempt to develop a theoretical model for understanding why these dualities exist by introducing the concepts of the megaevent utopia, dystopia and heterotopia.

A Mega-event utopia is ideal, imaginary, and grand urbanism embracing abstract concepts about econo- 
mies, socio-political systems, spaces, and societies in the host during mega-events. The term "grand" urbanism is leaning on Bishop and Williams (2012, p. 7) definition of temporary mega-events that permanently change urban fabrics. While the mega-event utopia is theorized as a temporary state (only present during mega-event staging), the temporary concept also encapsulates the idea of a mega-event-legacy utopia that is the visioning of idealistic long-term consequences and possibilities mega-events enable and, indeed, which make them so attractive to host cities. Megaevent utopias are dictated by the desires of megaevent owners ${ }^{1}$ irrespective of the realities in the host city. In short, a mega-event utopia is the perfect megaevent host from the owner's perspective; in planning and conceiving of mega-events, mega-event owners, planners and bidders have utopian visions about megaevents, including a strong sense of what an ideal host will be like during the event and which legacies the event is able to leave in the host. Such utopian visions, however, ignore the specific conditions that exist within the bidding city or nation and disregard possible negative legacies their utopias could leave in hosts. This counter-concept, the mega-event dystopia, is completely flawed urbanism. In mega-event dystopias, urban problems are exacerbated. Most recently, this concept has evolved through advocacy of anti-Olympic groups around narratives of forced evictions, displacements, and failed mega-projects built for mega-events.

Introducing the mega-event utopia and dystopia concepts suggests a model that can explain the wellknown discrepancy of problematic legacies post-event. Because different utopian and dystopian visions by various stakeholders encounter each other and the realities in hosts, heterotopian legacies are created. Because the mega-event utopia is a powerful force that shapes cities, a mega-event heterotopia as a hybrid post-event landscape manifests the temporary megaevent utopia as legacy imprints (for better or worse) into the long-term realities in hosting cities. It is not my intent to explain how mega-event heterotopias form when utopias and dystopias encounter the mega-event utopia and consequently adapt, change or reject each other during the stakeholders' planning and decisionmaking process (this shall be left to another paper). Instead, I introduce one very powerful utopia, the megaevent utopia, as a stepping stone towards a planning theory on mega-events, which the founders of megaevent legacy research, Stephen Chalkley and Brian Essex (1999, p. 391), have been advocating for almost two decades.

Theorizing mega-events and their contribution to urban change, is a critical but missing piece in the

\footnotetext{
${ }^{1}$ Mega-event owners are overseeing bodies for mega-events, e.g. the International Olympic Committee (IOC) for the Olympic Games.
}

evolving mega-event literature. The core of my theoretical work is the conceptualization of one utopia as an idealistic idea about what mega-events can be (mega-even utopia by owners) and what they can achieve (the mega-event legacy utopia operationalized by bidders). Conceptualizing one mega-event utopiathereby suggesting the existence of others-is a potential sensitizing device to orient legacy research in an attempt to bring some theoretical clarity to debates of the significance mega-events have in cities. As utopian visions increasingly find their way into mega-event bids, this theoretical grounding of urban change through mega-events is of high importance.

The novelty of the mega-event utopia concept lies in its approach to understanding, studying, interpreting and ultimately leveraging legacies. This concept is a deductive approach for studying legacies by exploring pre-disposed desires, expectations, and requirements mega-event owners set on hosts in contrast to the frequently-used inductive approach for studying legacy outcomes after they emerged. Not only does the deductive view provide a new lens to interpret legacies, but also to predict legacy developments as event requirements continue to evolve and change. If future hosts can foresee such legacies before they bid, they can efficiently leverage desirable ones (Grix, 2014; Smith, 2014). I develop the Olympic utopia as an example of the mega-event utopia concept. I do so through grounded theory using primarily empirical evidence collected as a staff member of Boston's 2024 Olympic bid. Boston's bid is a representative case, because it reflected utopian ideals through bidding and encountered dystopian vision that prematurely ended the bid. It is in interview-reflections of staff members post-bid that a heterotopian framework evolved.

\section{The Urban Planning Aspiration of Utopias and the Beginning of the Olympic Utopia}

To ground the mega-event utopia concept in theory, the merging of two research streams is of particular relevance. The first is the utopian concept in planning theory; the second is mega-events as an increasingly sought-after tool for urban change. The word U-topia has its origins in Greek, formed by the words "ov" or

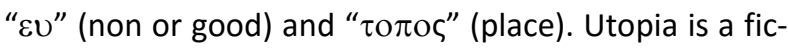
tional place that portrays an ideal, yet unrealizable, setting in space, time, and society. Historically, the first proposal for an utopian society was written by Plato, a Greek philosopher (380 BC), in "The Republic." Coincidentally, the Olympic utopia is rooted in the same place and time of origin. The ancient city of Olympia is located on a Greek plain in the northwestern Peloponnese. In Olympia, the ancient Olympic Games were held every four years between 776 BC-394 AD (Clarysse, Remijsen, Haiying, Jing, \& Xiang, 2012).

Reintroducing the concept of "Utopia", Thomas 
More (1516) philosophically described an ideal sociopolitical system and the spatial configuration of a fictional island nation. The utopian concept was reborn some centuries later in the USA and Europe, as a response to extraordinary urban change. The industrial revolution had brought an unprecedented acceleration of growth, raising living standards of the wealthy but creating numerous urban problems, including air and water pollution, overcrowding, inadequate sanitation, and race and class inequity. In response to these new problems, urban utopians developed uncompromising ideals on how to change the new misery of city living. Across the western world, utopian planners like Le Corbusier (the Radiant City), Daniel Burnham (the City Beautiful), Ebenezer Howard (the Garden City), and Frank Lloyd Wright (the Broadacre City) sought to remove the filth and squalor that accompanied the exponential growth of cities. Even though the utopians differed in their visions of how cities should be, all proposed radical and comprehensive changes to the physical layout of cities to permanently resolve concurrent problems of the industrial society.

Around the same time, mega-event owners were founded such as the International Olympic Committee (IOC) in 1894. Over time, the IOC just like other megaevent owners (FIFA founded in 1904) developed visions for their events reaching far beyond showcasing athleticism. These include building a better world through peace, education, friendship, solidarity and fair play. Similar to the evolution of the mega-event owner visions, the Olympic Games, the World Cup, and the World's Fair have advanced from needing small scale urban interventions to large scale transformations (Chalkley \& Essex, 1999; Essex \& Chalkley, 1998; Gold \& Gold, 2011; Hiller, 2006; Liao \& Pitts, 2006). These transformations now require billions of dollars in investments to produce an impressive legacy (Cashman, 2011; Short, 2008), while the widely advertised developmental effect of mega-events for much-needed urban projects is a highly anticipated benefit for hosts (Cashman, 2006, 2011; Hiller, 2006). For an Olympic host, these projects must include sporting, media, transport, tourism and accommodation features (Wilson, 1996) that are presentable on the world stage (Roche, 2003).

Leveraging positive legacies through mega-events has long been an aspiration of bidding cities. Megaevents are primarily regarded as powerful catalysts that can transform metropolises within a few years rather than several decades (Chalkley \& Essex, 1999; Gold \& Gold, 2016). Despite this knowledge, leveraging megaevents to the advantage of their hosts has been a challenge as competing mega-event demands have required a reorientation of resources for long-term endeavors in favor of more pressing short-term needs (Broudehoux, 2007; Jago, Dwyer, Lipman, Daneel van, \& Vorster, 2010; Smith \& Fox, 2007). The key in successfully leveraging legacies is early anticipation, strategic planning for local stakeholder aims, and wholesome integration into longterm plans of the host (Grix, 2014; Smith, 2014).

Mega-events are good for governmental leaders, elites and boosters, because they are perceived to bring positive legacies such as economic growth, world-city status, urban regeneration, and positive memories (Cornelissen, Bob, \& Swart, 2011; Gratton \& Preuss, 2008; Malfas, Theodoraki, \& Houlihan, 2004; Preuss, 2015, 2016; Ritchie, 1984). Their rigorous pursuit to bid, the mega-event strategy (Burbank, Andranovich, \& Heying, 2001), has sacrificed planning means over planning outcomes. In contrast, planning a good city entails not only planning outcomes of human flourishing and multipli/city but also planning means in form of good governance on the merits of transparency, public accountability, inclusiveness, responsiveness, inspired political leadership, and non-violent conflict resolution (Friedman, 2012).

\section{Methodology}

My analysis focuses on the mega-event owners' concept of the mega-event utopia. I will develop a megaevent utopian concept based on the criteria explicitly laid out by the mega-event owners in writing or during interviews and implicitly derived from their actions taken during bidding and candidacy (Table 1). Through grounded theory, I identify the four most prominent urban vision and legacy traits that perceivably define hosts' transformations through mega-events: Economy, image, infrastructure, and society.

To emphasize, mega-event utopias are imaginative, planning-theoretic and visionary with limited reference to reality. They entail creating the perfect host for staging mega-events. In practice, the idea of an ideal host has been proposed repeatedly. For example, Andreff (2012) and Goslett (2012) suggest one Olympic city or Platini suggests a continent-wide UEFA cup with 12 hosts (Bond, 2012). Through the conceptualization of mega-event utopias, I explain the legacy creation process as a systematic pattern that can be derived.

\section{Mega-Event Utopias}

Mega-event utopias exist because of idealism, imagination, and flights of fancy. They cater to the aspirational sportsmanship of citius, altius, fortius (swifter, higher, stronger). During a mega-event the dream to break a world-record must come to reality. Consequently, the mega-event utopia (Figure 1) creates a type of temporary environment in the host during the event to stage perfectionism. This includes an all-gain, no-risk economic strategy ensuring the mega-event takes place, an athlete experience in a dream-like atmosphere, and perfect built environments through venue, access and accommodation infrastructures. All of this enjoys $100 \%$ public support. 
Table 1. Data sources and methods.

Elite interviews with IOC
members and bidding committee
members ( 26 total)

1) Which considerations about a bid take center stage?

2) What role does the IOC play in creating legacies?

3) Where do you see the requirements for legacies evolve?
Ethnography as staff member of

Boston 2024 bidding corporation (3 months)

1) Topics dominant in meetings with US NOC, members of the mayoral office, city interest groups, public hearings and internal staff meetings on legacy

2) Topics dominant in personal interactions with CEO and the three VPs of Boston 2024

\section{Content analysis of}

bidding questionnaires from the IOC, intermittent bidding negotiations and agreements, charters, requests for bid alterations made by the mega-event owners, presentations given by bidding cities and mega-event owners, and technical manuals that lay out minimum benchmarks that specify necessary and desired conditions during mega-event staging.

Used to define traits of the mega-event utopia

Details on mega-event (legacy) utopia

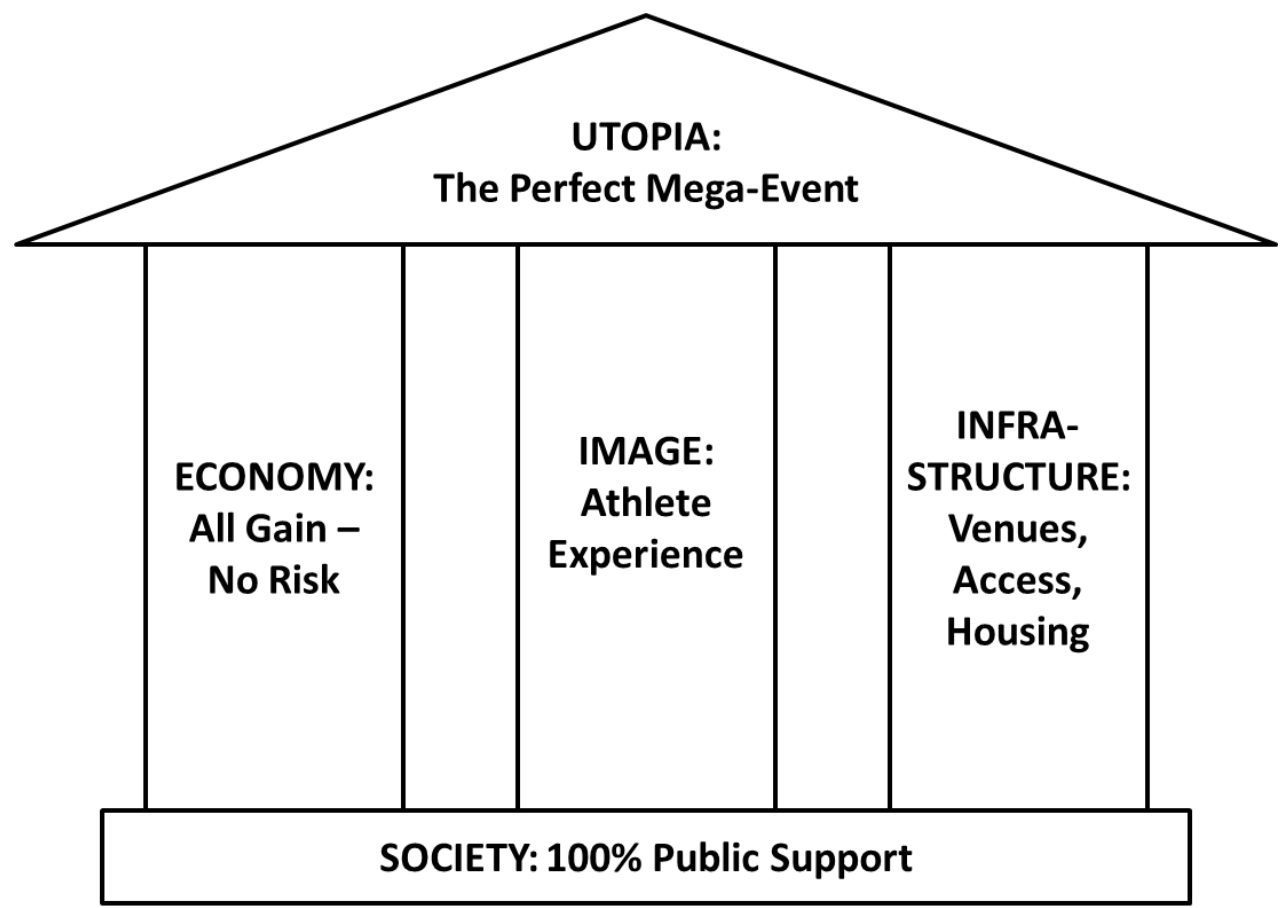

Figure 1. The mega-event utopia.

Bidders localize these mega-event utopias through mega-event legacy utopias. It is in the intersect of public acceptance and the temporality of the event that the mega-event-legacy utopia is placed, by envisioning the temporary mega-event utopias as stepping stones for the creation of longer-term 'goods'. In the megaevent discourse, these envisioned goods have been branded as expected positive legacies and have since then become an integral part of pursuing the megaevent strategy (Andranovich, Burbank, \& Heying, 2001). It is this visioning of the long-term ideal, the mega-event-legacy utopia (though I fold it into the term mega-event utopia in the following analysis), that connects the temporality to permanence: the vision for continuous economic development of the region, for becoming or remaining a world destination city, for accelerated urban regeneration, and for engaged citizens. These ideals are good urban planning. A planning process with high formal citizen participation, and decision-making has become the hallmark of good urban planning (Fischler, 2012), so have neoliberal outcomes such as economic growth, world city status, and urban regeneration projects that in turn are perceived to make cities livable and attractive places.

Exemplary for the mega-event utopia, I theorize the concept of the Olympic utopia. Staging the perfect Olympic Games in a host city creates economic benefits, provides the perfect athlete experience that spurs 
competitors to achieve the best results of their lives on a global stage, allows access to perfect stadia and housing, and enjoys $100 \%$ public support. The closer a bid matches the Olympic utopia, the likelier the city is selected for the Games, because "the official discourse is that the Games go to the best technical bid" (Interview IOC legacy consultant and former bidder 2012). The IOC evaluates each bidder against technical benchmarks for 14 bid themes ${ }^{2}$ (communicated by the USOC on January 22, 2015). However, the winner of the bidding process is selected through other flights of fancy via a vote casted by individual IOC members that have personal preferences:

"To win the bid, B2024 will have to demonstrate that the Olympic Games experience that will be delivered by Boston will be exceptional, and compelling in comparison to the other candidate cities. This means that B2024 has to show how its Games will be technically superior, meeting or exceeding the criteria of the International Sports Federations, the NOCs, the Media, the Broadcasters, the officials, and the IOC. It must offer a compelling, and thoughtfully developed experience for the athletes and other client groups. It should be innovative, bringing new ideas, new solutions to the Olympic Games. And, it must have the "wow" factor. The IOC describes this as EXCELLENCE, RELEVANCE, INSPIRATION and INNOVATION." (Source: Box 2024) 3

\subsection{The All-Gain, No-Risk Strategy-The Utopian Economy}

The Olympic utopia artificially creates an economic benefit for the $I O C$ at zero risk. The $I O C$ requires all host cities to sign a guarantee, in which the host city assumes all risks associated with the staging of the Olympic Games. While the bid city commits to absorb all cost overruns, broadcasting rights and ticketing revenues of the Olympic Games are slated to become more than half of the IOC's revenue sources (IOC, 2015). Furthermore, the host city must pay fees to the IOC. For example, the application fee for submission of the bid file officially is $\$ 250,000$, but unofficially is estimated to be twice as much (Source: Box 2024) ${ }^{4}$.

Bidding cities have until recently signed the host guarantee without questions, because the Olympic

\footnotetext{
${ }^{2}$ Candidate file themes: 1 . Vision, Legacy and Communications, 2. Overall concept of the Olympic Games, 3. Political and public support, 4. Legal aspects, 5. Environment, 6. Finance, 7. Marketing, 8. Sport and venues, 9. Paralympic Games, 10. Olympic Village(s), 11. Games Safety, Security and Medical Services, 12. Accommodation, 13. Transport, 14. Media Operations.

${ }^{3}$ Sources not publicly available, collected during ethnographic research in bidding city.

${ }^{4}$ Sources not publicly available, collected during ethnographic research in bidding city.
}

Games have been perceived as an economic motor offsetting associated costs. Projected economic impacts come from tax revenues of the developed lands for retail, hotels, housing, parking and office space, from ticket sales, from broadcasting rights, from sponsorships and from marketing. Boston 2024 described bidding for the Games as a way to "capitalize on one of the largest economic development opportunities in recent history" (Boston 2024 presentation of Bid 2.0 in July 2015, p. $7^{5}$ ). This economic growth opportunity would create significant jobs, substantially increase housing, and substantially raise city revenue. The bidding committee promised to channel investments into local communities for workforce development, youth development, and business opportunities.

\begin{abstract}
"You need to build a zero sum process for the operation of your organizing committee, which basically means you have a zero sum budget, you spend what you need, and you are able to work with developers within the city to produce the kind of infrastructure that is required for the Games. What's the benefit of that? If I were to come to you as the mayor of the city and say, look, l've got a proposal for you. I'm going to generate about $\$ 10$ billion worth of business over the next 7 years, are you interested? What would your answer be?" (Source: Interview Consultant 2015)
\end{abstract}

Supported is the argument for the Olympic Games as an economic opportunity based on successful hosting examples, most notably the LA Games in 1984 regarded as the most profitable Games in history. The economic revenues reached into the nine-digits, making Los Angeles a \$200million profit.

\subsection{The Athlete Experience-The Utopian Image}

The Olympic utopia artificially creates the perfect atmosphere for athletes to compete. In video presentations (headquarters IOC Lausanne, presentations to potential 2024 bidding cities in May 20156), sports victories, gold medalists, and winning teams held center stage. The videos show the most memorable moments in Olympic history. Watching these videos stirs memories and creates hopes for victories causing goosebumps. This excitement translates into bidders:

"There's something magical about sports...it makes the Olympics magic. I think the best day was when we won the domestic bid, and people were so excited for Boston, across the globe, and there was this

\footnotetext{
${ }^{5}$ Sources not publicly available, collected during ethnographic research in bidding city.

${ }^{6}$ Sources not publicly available, collected during ethnographic research in bidding city.
} 
moment of history in the bid where there was hope and excitement and people were able to think big." (Source: Boston 2024 Chief of staff to CEO and COO)

In conversations with various consultancies on how to win the 2024 Olympic bid, emphasis was placed on how to "wow" the International Olympic Committee. At the center of those discussions was the athlete experience: "the city must demonstrate that it will present an atmosphere that will spur athletes on to the best results of their lives" (Source: Box 20247). Suggestions included permanent housing for athletes in the Olympic Village, an Olympic center dedicated to the Olympic Movement, an Olympic museum displaying the history of the Games, and a symposium series across Massachusetts on Olympic History and Impact: "We could let athletes talk about stories, about legacy and how the Olympics changed their lives" (Interview with Boston 2024 director of athlete engagement and sport legacy 2015).

While the athlete experience centers on the local conditions, it also is important to broadcast this atmosphere to the world. This global visibility has been seen as an opportunity for bidding cities to showcase unique aspects and gain world-city status. For Boston, that meant "highlighting its innovation economy and world-class institutions and raising Boston's profile even higher on the global stage." This in turn was believed to attract more investment, commerce, talent, and tourism (Boston 2024 stakeholder presentation of Bid 2.0 in July 2015, p. $7^{8}$ ).

\subsection{Venues, Access and Accommodation-The Utopian Infrastructure}

The ideal form, geometry, and infrastructure siting for athletic competitions is reflected in the space Olympic utopia that artificially creates the perfect built environment for athletes. This includes (a) closely-located venues, (b) minimized travel times for athletes to access the venues, (c) high-quality secured athlete housing, and (d) sufficient spectator crowds that have high-speed, highcapacity access to venues. Consequently, utopias are spatially defined by the functions they have to fulfill during mega-events (Figure 2). Historically, the utopian design of an Olympic city reflects the ancient city of Olympia. All athletes from different Greek tribes competed in the Olympic Park, where the competition venues were grouped together. Next to the adjacent Athlete Village and training facility, an Olympic hotel hosted visitors and public space was available for tents in the shadow of the pine forests near the Alfeios river. The modern Olympic

\footnotetext{
${ }^{7}$ Sources not publicly available, collected during ethnographic research in bidding city.

${ }^{8}$ Sources not publicly available, collected during ethnographic research in bidding city.
}

Games would not fit into the ancient utopia "Olympia" due to their increased attendance (from 50,000 to several million visitors), number of competition venues (from $\sim 3$ to $\sim 30$ ) and athletes (from $\sim 200$ to $\sim 10,500$ ) (Chappelet, 2012; Clarysse et al., 2012).

The perfect geometry of the built environment is a circle to minimize distances. The main stadium sits in the center of the modern Olympic utopia, circled by 29 venues, whereby each has a minimum seating capacity and for security separate entrances for spectators and athletes. The circular utopian configuration maximizes convenience, security, safety for athletes, and minimizes their travel times to the venues. To optimize locational access, athlete housing is directly adjacent to the venues and holistically integrated into the Olympic Park, which is 24/7 access-secured. The utopian central ring labeled as Olympic Village/Parklands, is surrounded by a secondary ring of hotel clusters outside the Olympic Parklands, where Olympic Family members, the International Broadcast Center (IBC) and Main Press Center (MPC) are located.

Transportation in the Olympic utopia is primarily focused on providing point-to-point high-frequency services for visitors and athletes from the main accommodation areas to the competition and noncompetition venues (IOC, 2008, pp. 67-110). While the IBC, MPC, IOC hotels, and judges' accommodation are located along exclusive bus routes, visitor hotels are at the high-capacity rail stations. Visitor transportation is provided by a looped access ring. Because peakdemands on transportation systems from Olympic visitors are roughly 1-2 million additional travelers per day, rail transport is most efficient (Bovy, 2004).

"Of course the IOC would like every Olympic venue to be connected by high-capacity public transport systems.... The London Olympic park is in fact a rail yard. Seven lines are arriving, leaving from, or going through the Olympic park. So, the IOC was happy about it." (IOC legacy consultant and former bidder 2012)

Locating athlete housing close to or integrated with the center of Olympic competition activity, minimizing travel time, and providing high reliability of the transportation system has historically received higher marks from evaluation commissions (IOC, 2009a, 2009b). Especially in early years, many host cities closely resemble the Olympic Utopia by clustering venues in an Olympic Park. Over recent years, different clustering strategies have been explored by hosts, in an attempt to spread economic benefits, integrate historical landmarks, use pre-existing stadia, or pursue ambitious long-term urban plans by using the Summer Olympic Games as a catalyst for urban development (Table 2). 


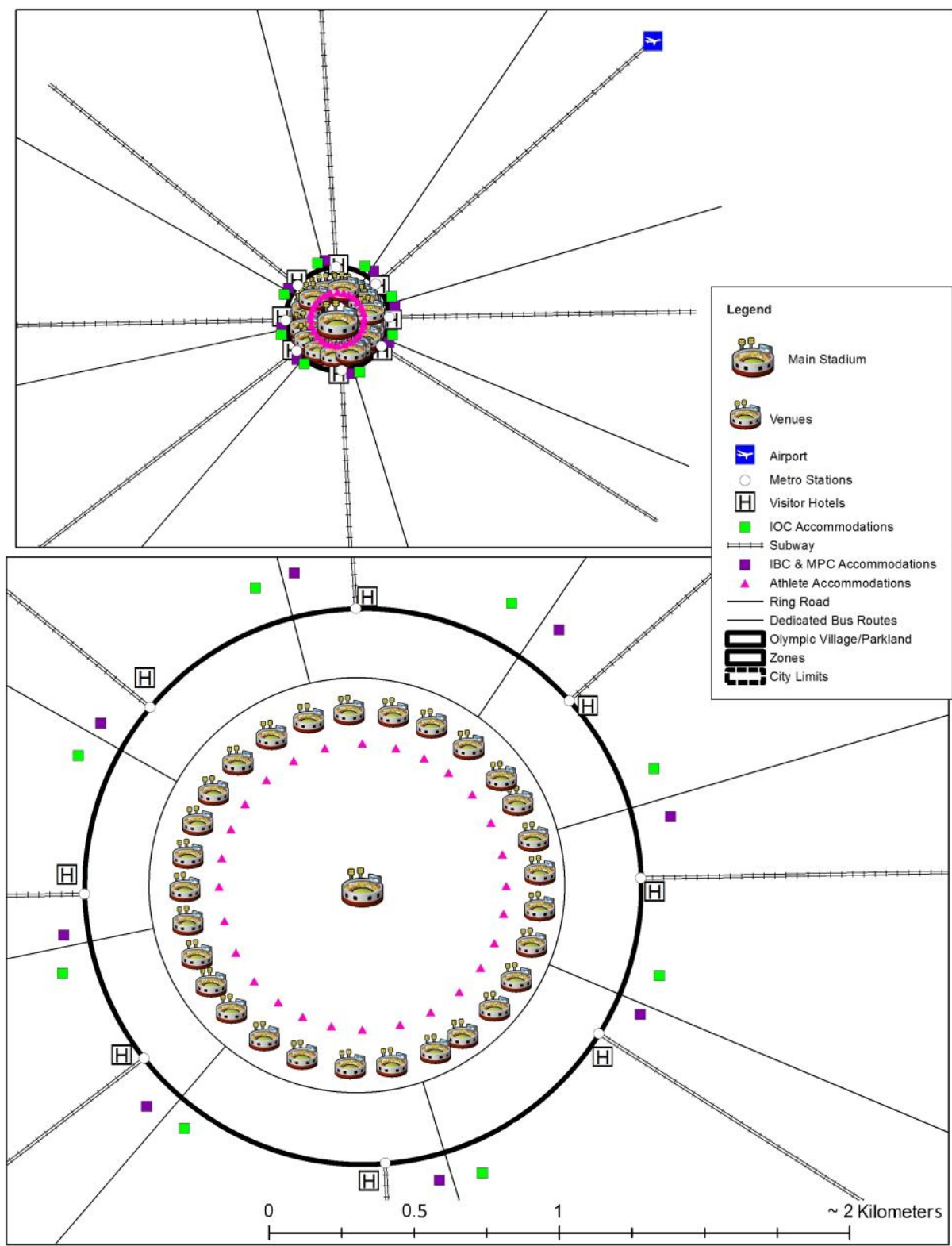

Figure 2. Utopian design of the Olympic city. Source: the author.

Table 2. Venue Clusters at the Summer Olympic Games

\begin{tabular}{lllll}
\hline & One venue cluster & Two venue clusters & Three venue clusters & Four venue clusters \\
\hline Host & Amsterdam (1928), LA (1932), & Rome (1960), Tokyo & Athens (2004) & Barcelona (1992), Rio \\
City & Berlin (1936), Helsinki (1952), & (1964), Seoul (1988), & de Janeiro (2016) \\
& $\begin{array}{l}\text { Melbourne (1956), Munich (1972), } \\
\text { Montreal (1976), Atlanta (1996), }\end{array}$ & & \\
& Sokyo (2020) & & \\
& Londney( 2000), Beijing (2008), & & \\
\hline
\end{tabular}

Source: the author, Amsterdam 1928 pioneered the clustered event site, building the first Olympic Village on reclaimed land. First, the author classified a cluster as three or more venues within walking distance. Venues were mapped out by identifying their coordinates. Missing location data was excluded, hence cluster percentages were potentially under reported. Excluded are host cities (after 1928) with a dispersed venue structure. Second, the initial cluster was compared to writings in the four volumes of Gold and Gold (2012) and adjusted accordingly.

Bidders respond to urban infrastructure needs by emphasizing that Olympic demands would "catalyze transportation investments and connect neighbor- hoods". The legacy left behind would be more green space, better connectivity, and more active transportation like biking and pedestrian access (Boston 2024 
stakeholder presentation of Bid 2.0 in July $2015^{\circ}$ ). At the same time bidders are thinking about the wowfactor and uniqueness their city could provide to the IOC. For example, the wow-factor that Hamburg intended to offer was making the Olympic Games a permanent and defining feature in the skyline of Hamburg. These included a new urban neighborhood to be called "Olympia city" (renaming the Kleine Grasbrook), an Olympic stadium turned into permanent housing, an Olympic hall turned into a cruise ship terminal, and an Olympic pool turned into a recreational pool and sport center. The new urban neighborhood with its permanent features, so Hamburg's bidding committee believed, would create a competitive advantage over other bidders, like Los Angeles, in which the Games would not be able to leave a permanent mark.

\subsection{0\% Public Support-The Utopian Society}

An Olympic utopian society supports without any doubt the Olympic Games, the Olympic movement, Olympic values, and their expected legacies.

"To win, Boston must present a compelling case for the voters [the IOC members]. The city must appear excited and welcoming to the Games" (Source: Box $\left.2024^{10}\right)$.

In order to create support from all local stakeholders, bidders have fostered "unprecedented collaboration across the city" with the legacy goal for "great civic pride, unity and inspiration" (Boston 2024 stakeholder presentation of Bid 2.0 in July $2015^{11}$ ). Under the banner of the unifying power of sport, bidders set aspirational goals dove-tailing the mega-event owners' unity aspirations. For example, former chairman of Boston 2024, John Fish, said that this generation was the first one to leave the USA worse off than the one beforehe added that an American Olympic Games would be able to change this. Previous hosts and bidders describe this unifying power of planning through its ability to bring different stakeholders together who were unable to come to an agreement without the Games.

"The power of unification of the mega-event and its ability to rally so many different aspects of the community around bringing your city on a world stage. That was what was resoundingly clear when we brought in any other host city, you have no idea about the tremendous power of unification when your city

\footnotetext{
${ }^{9}$ Sources not publicly available, collected during ethnographic research in bidding city.

10 Sources not publicly available, collected during ethnographic research in bidding city.

${ }^{11}$ Sources not publicly available, collected during ethnographic research in bidding city.
}

is expecting the world for 3 or 4 weeks" (Boston 2024 Chief Marketing and Communications Officer).

To maximize support, the best interests of various stakeholders have to be integrated into the bid. Therefore, Boston 2024 organized a symposium series titled "Boston Futures." It discussed the realm of Boston's possibilities as a city and ultimately how the Olympic Games could support such possibilities. Former Boston Mayor Menino described the entrance of the Olympic bid as a vehicle for conversations that had not happened in the last 30 years. "I enjoy being a part of a big civic initiative that was really going to have a big impact on the city and a long term impact and was bringing a lot of people together from across the city" (Boston 2024 VP of International Strategy). In parallel, new Boston Mayor Walsh inaugurated an ambitious project "Envision Boston 2030 " to set the city's agenda for the next decades.

Generalizing, mega-event utopias share certain characteristics, they require specialized infrastructures to be erected in host cities, they create a mega-event society supportive of the event, they enjoy broad political support, and they are used to claim or maintain world-city status. As far as utopias go, the visions of the mega-event owners are global, all-encompassing, and aspirational while the mega-event embodies the proclamation and manifestation of their utopias.

\section{Mega-Event Heterotopias and Dystopias}

Over the past decade, the term "catalyst" has dominated much of the discussion on mega-events and urban development (Chalkley \& Essex, 1999; Coaffee, 2011; Essex \& Chalkley, 1998; Hiller, 2000; Kontokosta, 2012; Poynter \& MacRury, 2009; Steinbrink, Haferburg, \& Ley, 2011). Catalyst is an often-used, incorrect and simplistic term to describe urban transformations in hosting cities; catalysts by definition accelerate processes, but do not alter them. Because mega-events have turned from a tool to an agent that plays a significant role in urban policy (Chalkley \& Essex, 1999), a more nuanced definition and understanding that causally connects the planning for legacies to their implementation is essential. It is not my intent to dissect the complex decision-making process leading to local legacies, instead I propose the concept of the mega-event heterotopia as a sensitizing device to orient legacy research.

Mega-event heterotopias are the accumulation of legacies in hybrid post-event urban systems. Heterotopias were originally introduced by Michel Foucault (1967), who considered the consequences when utopias are sought to be put into place. Mega-event heterotopias manifest the temporary mega-event utopia (just like other utopian and dystopian visions) as legacy imprints into the long-term realities in hosting cities. For example, the Olympic transformation has an IOC legacy pattern: 
Through asking for detailed information in the bidding phase, it forces the candidate cities to start implementing what will become the working foundation of their future legacies. The IOC...defines this legacy through the questions on the subject contained within our Candidature documentation. (IOC Head of Sustainability and Olympic Legacy, 2013)

One such legacy-question asks to what extent the expected legacies align with local urban planning goals. Depending on the suitability of the fit between the mega-event utopia, other stakeholder visions, and local conditions, discrepancy of outcomes can be observed. For example, while we saw better alignment in Barcelona between both, in Rio we see a clash between the mega-event utopia and the locale. While the urban visions in Rio's 2016 Olympic bid books (2009) are positively aligned, the heterotopian evolution of legacies we witness in Rio de Janeiro is terrifyingly different due to the locale and other stakeholder visions. Like the history of utopic thinking in urban planning, which is littered with lessons of abject failures, the history of Olympic staging has created dystopias. Dystopia, which also has its origins in Greek $\delta \cup \sigma-($ bad, hard) and tóroৎ (place) is an undesirable place and society. As the Olympics transform Rio, they artificially create utopic places to house athletes by forcefully relocating urban slums (Vale \& Gray, 2013). Similarly, the utopic notion of public support for the Games (and its legacies) promised in the bid books has been shattered by local protest movements, strategic gentrification, and public-space militarization (Gaffney, 2013, 2015).

The heterotopian mega-event concept proposed here reaches far beyond the notion of Olympic urbanism (Munoz, 2006; Viehoff, Poynter, \& Carmona, 2015). The concept of the mega-event heterotopia distinguishes itself from Olympic urbanism as follows: rather than being an ex-ante study of actual impacts, the mega-event heterotopia is deductible as idealistic or worsts from diverse stakeholders through pre-event conceptions, broader scale, and its co-influence, co-dependence, and coexistence of legacies. Exemplary rather than focusing on Olympic infrastructures (most notably the Olympic village), heterotopias consider the city-wide urban "othering" of mega-events as they manifest the variety of uand dystopias as legacies into the economy, image, infrastructure, and society of the host (Table 3 ).

Table 3. Mega-event utopias, mega-event dystopias, and mega-event heterotopias.

\begin{tabular}{|c|c|c|c|}
\hline & Utopia (temporary \& legacy) & Dystopia (temporary \& legacy) & $\begin{array}{l}\text { Ephemeral Planning for } \\
\text { Heterotopias }\end{array}$ \\
\hline ECONOMY & $\begin{array}{l}\text { All gain: no risk } \\
\text { Profit-generating, no risk } \\
\text { strategy through guarantees, } \\
\text { support by public, increased } \\
\text { economic activity, influx of } \\
\text { external capital, increased } \\
\text { tourism } \\
\text { Ex: Los Angeles }\end{array}$ & $\begin{array}{l}\text { All risk: no gain } \\
\text { Cost-overruns of mega-projects } \\
\text { and mega-event staging } \\
\text { Ex: Sochi }\end{array}$ & $\begin{array}{l}\text { Shared gain, shared pain } \\
\text { Economic Development of a } \\
\text { region: Profit/Cost-sharing } \\
\text { approach with mega-event } \\
\text { owners, insurance, equal } \\
\text { distribution of benefits }\end{array}$ \\
\hline IMAGE & $\begin{array}{l}\text { Athlete experience } \\
\text { World-class city, memories, } \\
\text { attractiveness, sportive, elitist, } \\
\text { cultural amenities, media } \\
\text { attention } \\
\text { Ex: London }\end{array}$ & $\begin{array}{l}\text { Resident experience } \\
\text { Security city/terrorism, grass } \\
\text { roots } \\
\text { Ex: Rio de Janeiro }\end{array}$ & $\begin{array}{l}\text { City experience } \\
\text { Local place-marketing: safe, } \\
\text { inclusive, visioning exercise for } \\
\text { cities }\end{array}$ \\
\hline $\begin{array}{l}\text { INFRA- } \\
\text { STRUCTURE }\end{array}$ & $\begin{array}{l}\text { Venues \& Accessibility } \\
\text { Master planning - large scale } \\
\text { development projects, eg } \\
\text { cleaning up of brownfields, new } \\
\text { city part, } \\
\text { Ex: Barcelona }\end{array}$ & $\begin{array}{l}\text { Building \&Mobility } \\
\text { Traffic nightmares due to } \\
\text { construction (during), white } \\
\text { elephants (post) } \\
\text { Ex: Athens }\end{array}$ & $\begin{array}{l}\text { Urban System } \\
\text { Urban Development: existing, } \\
\text { flexible, transformable, multi- } \\
\text { purpose, temporal structures }\end{array}$ \\
\hline \multirow[t]{2}{*}{ SOCIETY } & $\begin{array}{l}\text { Silver bullet to solve urban } \\
\text { problems }\end{array}$ & $\begin{array}{l}\text { Bullet to increase urban } \\
\text { problems }\end{array}$ & Targeted legacies \\
\hline & $\begin{array}{l}\text { An event is } 100 \% \text { supported if } \\
\text { each individual would benefit } \\
\text { from mega-event staging } \\
\text { Ex: Atlanta }\end{array}$ & $\begin{array}{l}\text { Deviation of city resources, } \\
\text { distraction from urban priorities } \\
\text { Ex: Boston }\end{array}$ & $\begin{array}{l}\text { Engaged and informed citizens: } \\
\text { Fair trade offs, realistic } \\
\text { expectations }\end{array}$ \\
\hline
\end{tabular}


Ephemeral planning for the mega-event heterotopia must master the challenge to appeal to the hosting city (mega-event legacy utopia), to avoid negative legacies (mega-event dystopia), and to please the mega-event owner (mega-event utopia). In order to create heterotopian visions, "good plans [must] marry idealism and realism” (Fischler, 2012, p. 12).

\subsection{Economic Development of a Region}

Governments of host cities envision the mega-event legacy utopia to align with economic growth of their region. This utopian perception is frequently met by two dystopian visions (1) only elites profit from the Games, and (2) tremendous cost-overruns. There is plenty of evidence for both, most notably Russian mega-events (Müller, 2014, 2015a). Anti-Olympic groups propagate those dystopias along three trains of thought (No Boston Olympics, 2015; Nolympia Hamburg, 2015): 1) a recent failed mega-project that burdened the local regional economy, 2) residents are the only ones paying the bill for no benefits and 3) opportunity costs that will occur because the Games are a distraction from important day-to-day tasks. Dystopias have created powerful local grass-roots oppositions that can stop bidding in its tracks as residents have asked for justifications on why their city should bid for a mega-event and have received non-satisfactory answers.

Good planning has to offer fair risk-sharing between mega-event owners and bidders. A sharing agreement should distribute profits fairly and similarly share burdens like cost-overruns. This approach would result in a more realistic and accurate cost-estimating approach given it is in the best interest of both parties. Second, insurance should be acquired to protect against risks like cost-overruns. Mega-projects associated with mega-events run $350 \%$ over budget (Zimbalist, 2015). In sum, economic growth of the region, one of the steady goals of urban planning throughout the industrial, modern, postmodern and sustainable planning eras (Fischler, 2012), should be a secured outcome of good planning for a mega-event rather than a lofty goal.

\subsection{Local Place Marketing through Image Creation}

Branding a city and local place-marketing through the Olympics as a desirable utopian vision has been met by dystopian place-avoiding visions. Those were most notably created through the series of mega-events in Rio de Janeiro that have unleashed negative imagery of protests due to the violation of human rights (Gaffney, 2010, 2013). Social media has become the driving force in broadcasting such imagery as print media has been linked to mega-event proponents, e.g. local press cosponsored Hamburg's 2024 bid. In these dystopian vi- sions, residents have taken the center stage as victims of the mega-event planning process that has turned the city into police states governed through violence, fear, and injustice.

In order to create a local-place marketing strategy, the mega-event must be built on positive imagery and compensate fairly for potential losses. Put simply, cities are unwilling to make the trade-off of three weeks of utopian positive press against the dystopian press years leading up to the event dominated by negative imagery, such as cost-overruns, delays, violated worker rights, evictions, and displacements. Guarantees of none violations of human rights, no rent increases, ensuring minority, women and veteranowned businesses participate equally in business opportunities generated by the Games have to be designed jointly and signed publicly before a bid is submitted. To be considered well-planned, those guarantees have to carry public accountability, be inclusive, responsive, and transparent, assign responsibility and list consequences in case of noncompliance. Such guarantees would also be in the best interest of the mega-event owner, because the prestigious brand that the IOC, FIFA and BIE are selling has taken a serious hit over the last two years, as more and more cities decline to bid for the Olympics.

\subsection{Urban Development through Infrastructure}

Aligning the infrastructure utopias with what a city needs for its development is difficult and has lead some to argue that both should be disjoint (Müller, 2015b). Dystopias of urban development are called white elephant ${ }^{12}$ legacies; these legacies are undesirable permanent infrastructures and costly to maintain for the host such as unfilled stadia, empty public spaces, vacant accommodations, or underused transport lines. Athens' deteriorating stadia are traumatic examples.

To use a mega-event for urban development, bidding cities must use existing infrastructures, and design flexible, adaptable, temporal, transformable, or multipurpose structures. Investments must be aligned with good-city planning of material equality, cultural diversity, democratic participation, and ecological sustainability (Fainstein, 1999). Planned carefully, mega-events can provide for the better: more housing, more green space, and better urban transport-all needs cities around the world are seeking to meet. The challenge is that the investments have benefits for society at large for which some individuals are willing to accept a fair trade-off:

12 White elephants are precious animals and sign of the owner's status, prestige, and wealth. At the same time, they are very costly because these animals can not be put to work due to their statue. 
Mega-events require for people to think a little bit beyond themselves for it to be successful, and so often I think we heard the question what's in it for me here in Boston. And while I think that's a perfectly legitimate question, a big event has to be more than just that (CEO of Boston 2024 Partnership Inc.)

\subsection{Public Participation via an Engaged Society}

Bidding for the Games in democratic countries has become a decision that the public must make. Dystopian visions have dominated the decision-making process evident through the series of publicly rejected failed bids for the 2022 Winter Olympics and 2024 Summer Olympics.

We're not impacting the priorities of the city and the state, we are aligned with the priorities of the city and the state, and we are that forcing mechanism and that catalyst to get those things done that you the public say that we need to get done. A big part of the challenge we faced was that the public, and certainly the opposition, never believed that that would really be possible. And believed that this bid and subsequent host planning and executing of the Games would consume and overwhelm all other civic priorities at the state and city level. (Source: Boston 2024 Vice president of international Strategy)

In order to assess whether a mega-event can be beneficial to the city for regional development, local place marketing, and urban development, it must be publicly planned, decided on, and evaluated. In short, megaevents must be openly governed. Open governance has to be managed online serving as a knowledge repository, active participation portal, and public decisionmaking tool. Targeted legacies have to be identified that benefit the host and are essential for the Olympics, while burdensome legacies have to be evaluated against the risk and potential benefits the mega-event could bring. In governing openly, Healey (2003) suggests that communicative planning holds the potential to realize a "process dream"-an economically, environmentally, and socially sustainable society that embraced both collaboration and diversity to create a good city.

\section{Conclusions}

Legacies have been perceived as relatively unsystematic, place-specific outcomes of mega-event staging that can be grouped into various categories (Cornelissen et al., 2011; Malfas et al., 2004; Preuss, 2015, 2016; Ritchie, 1984). In contrast, I propose that legacieseconomical, pictorial, infrastructural, societal and so forth-are shaped by an imaginary ideal, the megaevent utopia. Therefore, what has been perceived as a somewhat muddled and messy legacy creation process has a systematic pattern that can be deduced through its mega-event utopia. Consequently, the mega-event utopia can explain the systematic creation of legacies and the reshaping of hosts and are one of the most powerful visions of modern times that can radically restructure urban systems.

As mega-events progress as ever more powerful transformers into this century, mega-event heterotopias as hybrid post-event landscapes continue to manifest the temporary mega-event utopia as legacy imprints into the long-term realities in hosting cities. In the context of globalization, mega-event utopias can therefore also provide a lens of interpreting how global forces shape local outcomes (Swyngedouw, 1992; Whittaker, 2011). As mega-events continue to grow in size, scope, and scale, legacies have become of crucial importance to bidders. Because bidding governments frequently adhere to the long-established mega-event ideals to win the bid, mega-event utopias have become real concepts that intervene in urban planning agendas and consequently deserve acknowledgement by planning theorists and practitioners as powerful utopias that transform contemporary cities.

Introducing the mega-event utopia, dystopia and heterotopia concepts suggests a model that can explain the well-known discrepancy of problematic legacies post-event. While I only introduced one megaevent utopia and exemplified its utopian imprints on hosts, mega-event heterotopias can shed light on how different utopias and dystopias of various stakeholders are negotiated, compromised and adapted. In understanding this legacy creation, the planning process instead of the planning outcomes has to become center-stage (Kassens-Noor, Wilson, Müller, Maharaj, \& Huntoon, 2015). Process-focused, the three concepts introduced here direct new thinking in relation to planning policy for grand urbanism plans. They raise new questions around which temporary and legacy utopian and dystopian visions diverse stakeholders hold for mega-events; how these change in the discourse of bidding or staging; how each vision is adapted, negotiated and changed in the heterotopia post mega-event; and how local political, institutional, economic and social setting, stakeholder, leadership, management strategy, economic and financial mechanism play their role in creating the heterotopian legacy landscape? These three concepts also could affect city bids when they start to be conceived around realistic expectations of what a mega-event could and should accomplish in the context of the mega-event utopia and the locale. Understanding the scale of discrepancy of visions of diverse localstakeholders with the mega-event utopia could also influence the $10 C^{\prime}$ 's decision making process in realistically judging the legacies their Games will leave in bidding cities. 


\section{Acknowledgments}

I thank Dr. Andrew Smith for his continuous encouragement to publish my theory on mega-events. I am also indebted to the many colleagues that provided constructive feedback to drafts of this article including Professors Janice Molloy, Trixie Smith, Manuel Colunga, Wen Li, Chris Gaffney, Martin Müller, and Mark Wilson.

\section{Conflict of Interests}

The author declares no conflict of interests

\section{References}

Andranovich, G., Burbank, M., \& Heying, C. H. (2001). Olympic cities: Lessons learned from mega-event politics. Journal of Urban Affairs, 23(2), 113-131.

Andreff, W. (2012). The winner's curse: Why is the cost of mega sporting events so often underestimated? In W. Maenning \& A. Zimbalist (Eds.), International handbook on the economics of mega sporting events (pp. 37-69). Northampton, MA: Edward Elgar Publishing, Inc.

Bishop, P., \& Williams, L. (2012). The temporary city. London: Routledge.

Bond, D. (2012, 6 December). European Championship: Uefa to hold 2020 finals across continent, $B B C$. Retrieved from http://www.bbc.co.uk/sport/0/foot ball/20631963

Bovy, P. (2004). High performance public transport: A must for very large events. Public Transport International, 53(2), 20-23.

Broudehoux, A. M. (2007). Spectacular Beijing: The conspicuous construction of an Olympic metropolis. Journal of Urban Affairs, 29(4), 383-399.

Burbank, M., Andranovich, G., \& Heying, C. H. (2001). Olympic dreams: The impact of mega-events on local politics. Boulder, CO: Lynne Rienner.

Cashman, R. (2006). The bitter-sweet awakening: The legacy of the Sydney 2000 Olympic games. Sydney: Walla Walla Press.

Cashman, R. (2011). Sydney Olympic park 2000-2010. Sydney: Walla Walla Press.

Chalkley, B., \& Essex, S. (1999). Urban development through hosting international events: A history of the Olympic Games. Planning Perspectives, 14, 369-394.

Chappelet, J. L. (2012). Have the Olympics become too big? Paper presented at the The Olympic Games: Meeting New Global Challenges, Oxford University Conference.

Clarysse, W., Remijsen, S., Haiying, Y., Jing, W., \& Xiang, W. (2012). Ancient Olympics. Retrieved from http://ancientolympics.arts.kuleuven.be/eng/TA000 EN.html

Coaffee, J. (2011). Urban regeneration and renewal. In J. R. Gold \& M. M. Gold (Eds.), Olympic cities, city agendas, planning and the world's games, 18962012 (pp. 150-164). New York: Routledge.

Cornelissen, S., Bob, U., \& Swart, K. (2011). Sport megaevents and their legacies: The 2010 FIFA world cup. Development Southern Africa, 28(3), 305-306.

Essex, S., \& Chalkley, B. (1998). The Olympic Games: Catalyst of urban change Leisure Studies, 17(3), 187206.

Fainstein, S. S. (1999). Can we make the cities we want? In S. Body-Gendrot \& R. A. Beauregard (Eds.), The urban moment (pp. 249-272). Thousand Oaks, CA: Sage.

Fischler, R. (2012). Fifty theses on urban planning and urban planners. Journal of Planning Education and Research, 32(1), 107-114.

Foucault, M. (1967). Des espace autres. Paris: Architecture/Mouvement/Continuité.

Friedman, J. (2012). The good city in defense of utopian thinking. In S. S. Fainstein \& S. Campell (Eds.), Readings in Planning Theory (pp. 87-104). West Sussex, UK: Wiley-Blackwell.

Gaffney, C. (2010). Mega-events and socio-spatial dynamics in Rio de Janeiro, 1919-2016. Journal of Latin American Geography, 9(1), 7-29.

Gaffney, C. (2013). Between discourse and reality: The un-sustainability of mega-event planning. Sustainability, 5(9), 3926-3940.

Gaffney, C. (2015). Gentrifications in pre-Olympic Rio de Janeiro. Urban Geography, 1-22.

Gold, J. R., \& Gold, M. M. (2011). Olympic cities-City agendas, planning, and the world's games, 18962012 (2nd ed.). London and New York: Routledge.

Gold, J. R., \& Gold, M. M. (2012). The making of Olympic cities. London and New York: Routledge.

Gold, J. R., \& Gold, M. M. (2016). Olympic Cities-City agendas, planning, and the world's games, 18962020 (3rd ed.). London and New York: Routledge.

Goslett, M. (2012, 23 July). Instead of disrupting a different city every four years, the Olympics should always be held in Athens, Mail Online. Retrieved from http://www.dailymail.co.uk/debate/article-2177650/ Instead-disrupting-different-city-years-Olympicsheld-Athens.html

Gratton, C., \& Preuss, H. (2008). Maximizing Olympic impacts by building up legacies. International Journal of the History of Sport, 25(14), 1922-1938.

Grix, J. (Ed.). (2014). Leveraging legacies from sports mega-events: Concepts and cases. Hampshire, UK: Palgrave Macmillan.

Grix, J., \& Carmichael, F. (2011). Why do governments invest in elite sport? A polemic. International Journal of Sport Policy and Politics, 4(1), 73-90.

Healey, P. (2003). Collaborative planning in perspective. Planning Theory, 2, 101-123.

Hiller, H. H. (2000). Mega-events, urban boosterism, and growth strategies: An analysis of the objectives and legitimations of the Cape Town 2004 Olympic bid. In- 
ternational Journal of Urban and Regional Research, 24(2), 439-458.

Hiller, H. H. (2006). Post-event outcomes and the postmodern turn: The Olympics and urban transformations. European Sports Management Quarterly, 6(4), 317-332.

Horne, J. (2007). The four 'knowns' of sports megaevents. Leisure Studies, 26(1), 81-96.

International Olympic Committee. (2008). Games of the XXXI Olympiad 2016 working group report. Lausanne, France: IOC.

International Olympic Committee. (2009a). Report of the 2010 IOC evaluation commission. Lausanne, France: IOC.

International Olympic Committee. (2009b). Report of the 2016 IOC evaluation commission. Games of the XXXI Olympiad. Lausanne, France: IOC.

International Olympic Committee. (2015). Revenue sources and distribution. Retrieved from http:// www.olympic.org/ioc-financing-revenue-sourcesdistribution?tab=sources

Jago, L., Dwyer, L., Lipman, G., Lill, D., \& Vorster, S. (2010). Optimising the potential of mega-events: An overview. International Journal of Event and Festival Management, 1(3), 220-237.

Kassens-Noor, E. (2012). Planning Olympic legacies: Transport dreams and urban realities. Oxford: Routledge.

Kassens-Noor, E., Wilson, M., Müller, S., Maharaj, B., \& Huntoon, L. (2015). Towards a mega-event legacy framework. Leisure Studies, 34(6), 665-671.

Kontokosta, C. (2012). The price of victory: The impact of the Olympic games on residential real estate markets. Urban Studies, 49(5), 961-978.

Liao, H., \& Pitts, A. (2006). A brief historical review of Olympic urbanization. The International Journal of the History of Sport, 23(7), 1232-1252.

Malfas, M., Theodoraki, E., \& Houlihan, B. (2004). Impacts of the Olympic games as mega-events. Proceedings of the Institute of Civil Engineers, Municipal Engineer, 157(ME3), 209-220.

Moore, T. (1516). Utopia.

Müller, M. (2014). How Mega-events capture their hosts: event seizure and the World Cup 2018 in Russia. Social Science Research Network. doi:10.1080/ 01944363.2015 .1038292

Müller, M. (2015a). After Sochi 2014: costs and impacts of Russia's Olympic Games. Eurasian Geography and Economics, 55(6), 628-655.

Müller, M. (2015b). The mega-event syndrome: Why so much goes wrong in mega-event planning and what to do about it. Journal of the American Planning Association, 81, 1-12.

Müller, M. (2015c). What makes an event a megaevent? Definitions and sizes. Leisure Studies, 34(6), 627-642.

Munoz, F. (2006). Olympic urbanism and Olympic villag- es: Planning strategies in Olympic host cities, London 1908 to London 2012. The Sociological Review, 52(s2), 175-183.

No Boston Olympics. (2015). Why oppose Boston 2024? No Boston Olympics. Retrieved From http://www. nobostonolympics.org/why_oppose_the_games

Nolympia Hamburg. (2015). Acht Mythen rund um die Hamburger Olympia-Bewerbung. Nolympia Hamburg. Retrieved from http://www.nolympiahamburg.de/mythen.html

Plato. (380 BC). The Republic.

Poynter, G., \& MacRury, I. (2009). Olympic cities: 2012 and the remaking of London. Farnham, UK: Ashgate.

Preuss, H. (2015). A framework for identifying the legacies of a mega sport event. Leisure Studies, 1-22.

Preuss, H. (2016). A theory of mega sport event legacies. In G. B. Cunningham, J. S. Fink \& A. Doherty (Eds.), Routledge handbook of theory in sport management. New York: Routledge.

Rio 2016. (2009). Candidature file for Rio de Janeiro to host the 2016 Olympic and Paralympic Games. Rio de Janeiro: Rio 2016.

Ritchie, J. B. R. (1984). Assessing the impact of Hallmark events: Conceptual and research issues. Journal of Travel Research, 23(1), 2-11.

Roche, M. (2003). Mega-events, time and modernity. Time \& Society, 12(1), 99-126.

Short, J. R. (2008). Globalization, cities and the summer Olympics. City: Analysis of Urban Trends, Culture, Theory, Policy, Action, 12(3), 321-340.

Smith, A. (2012). Events and urban regeneration. The strategic use of events to revitalise cities. Oxford: Routledge.

Smith, A. (2014). Leveraging sport mega-events: New model or convenient justification? Journal of Policy Research in Tourism, Leisure and Events, 6(1), 15-30.

Smith, A., \& Fox, T. (2007). From 'event-led' to 'eventthemed' regeneration: The 2002 Commonwealth games legacy programme. Urban Studies, 44(5/6), 1125-1143.

Steinbrink, M., Haferburg, C., \& Ley, A. (2011). Festivalisation and urban renewal in the Global South: sociospatial consequences of the 2010 FIFA World Cup. South African Geographical Journal, 93(1), 15-28.

Swyngedouw, E. (1992). The mammon quest: 'glocalization', interspatial competition and the monetray order: The construction of new scales. In M. Dunford \& G. Kafkalas (Eds.), Cities and regions in the New Europe. London: Belhaven Press.

Vale, L. J., \& Gray, A. (2013). The displacement decathlon. Places Journal. Retrieved from https://places journal.org/article/the-displacement-decathlon

Viehoff, V., Poynter, G., \& Carmona, M. (2015). Megaevent cities. Farnham, UK: Ashgate Publishing Limited.

Whittaker, T. (2011). Between the dirty and the pretty: Bodies in utopia in dirty pretty things. International 
Journal of Cultural Studies, 14(2), 121-132.

Wilson, H. (1996). What is an Olympic city? Visions of Sydney 2000. Media, Culture and Society, 18, 603618.

\section{About the Author}

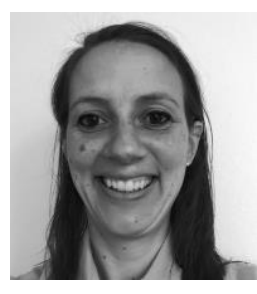

\section{Dr. Eva Kassens-Noor}

Eva Kassens-Noor is an Associate Professor of Urban and Transport Planning in the School of Planning, Design, and Construction at Michigan State University. She holds a joint appointment with the Global Urban Studies Program and is an Adjunct Associate Professor in the Department of Geography, Environment and Spatial Sciences. Eva Kassens-Noor is currently on sabbatical (2015/2016) as a Visiting Associate Professor in the Department of Urban Studies and Planning at the Massachusetts Institute of Technology. 